\title{
Effect of varying Number of Spacing between Antenna Elements, Snapshots, SNR on AP ML, AP-SSF and ESPRIT Algorithm
}

\author{
VINOD KUMAR, SANJEEV KUMAR DHULL \\ Department of ECE \\ GJUS\&T \\ Hisar \\ India
}

\begin{abstract}
The direction of arrival estimation is the main key problem in array signal processing. In this paper, the alternating projection maximum Likelihood (AP-ML), Alternating projection sub space framework (APSSF) and ESPRIT algorithm are studied. The simulation is performed in MATLAB for single and multiple sources. The effect of the varying number of spacing between antenna elements, number of snapshots and SNR are studied. The performance comparison shows that ESPRIT algorithm performs better as compared to the AP-ML and AP-SSF.
\end{abstract}

Key-Words: - AP-ML, AP-SSF, Direction of Arrival, ESPRIT, Snapshots, SNR.

Received: July 2, 2020. Revised: December 12, 2020. Accepted: December 22, 2020. Published: December 29, 2020.

\section{Introduction}

The main aim of the array signal processing is to process the incoming signal from the different directions and increase the signal strength by removing the noise and interference signal by collecting the desired signal parameter information. The ML methods have elite yet computationally costly. The subspace techniques are performed well and having computationally effective variations. The old style strategies are basic yet offer humble or lackluster showing and furthermore require an enormous number of calculations. In this the three algorithms are studied and the performance comparison of the three is studied in details.

\section{Alternating Projection Maximum Likelihood}

The AP-ML is a iterative based techniques for reducing the maximization problem from a multidimensional to single dimensional problem. This may be achieved by maximization according to a single parameter keeping other parameters fixed. The maximum likelihood provides an optimum solution at an array of sensors for the direction finding of multiple signals. The computational complexity is high in maximum likelihood $[2,4]$.

By assuming an array of sensors $(p)$ having different locations and $q$ be the uncorrelated narrowband signals that are impinging on the array from the directions $Q_{1}, Q_{2}, Q_{3} \ldots \ldots \ldots . Q_{q}$. the received signal at the antenna array is given by:

$x(t)=\sum_{m=1}^{q} a\left(Q_{m}\right) S_{m}(t)+n(t)$

Where, $x(t)$ is a $p \times 1$ received signal vector, $n(t)$ is a $p \times 1$ white noise vector with zero mean and covariance matrix of $\sigma^{2} I . \sigma^{2}$ and $I$ be the unknown noise variance and identity matrix. $S_{m}(t)$ be the signal emitted by the $m^{\text {th }}$ source and received at a reference point. $a\left(\theta_{m}\right)$ be the $p \times 1$ steering vector corresponding to the direction $\theta_{m}$. The ML estimate is to solves the $1-\mathrm{D}$ problem. The estimated angle is given by the following equation:

$\theta_{i}^{\hat{k}+1}=\max _{\theta_{i}} \frac{a\left(\theta_{i}\right)_{A\left(\theta_{i}\right) k}^{H} R a\left(\theta_{i}\right)_{A \theta_{i}^{k}}}{a\left(\theta_{i}\right)_{A \theta_{i}^{k}}^{H} a\left(\theta_{i}\right)_{A \theta_{i}^{k}}}$ 
where, $a\left(\theta_{i}\right)_{A\left(\theta_{i}^{k}\right)}$ is a $p \times 1$ vector.

Given by $a\left(\theta_{i}\right)_{A\left(\theta_{i}^{k}\right)} \equiv\left(I-P A_{\theta_{i}^{k}}\right) a\left(\theta_{i}\right)$

Where, $P A_{\theta_{i}^{k}}$ is a projection operator on to the subspace spanned by the columns of $A\left(\hat{\theta}_{i}^{k}\right)$ and $\mathrm{H}$ denotes the Hermitian Matrix.

\section{Alternating Projection SSF (Subspace Fitting Framework)}

This alternating projection is used to estimate the different parameters in subspace fitting framework and gives the relationship between different algorithms. This type of framework is generally used to designed numerical algorithms and used in obtaining new methods. The extension of the ESPRIT algorithm is designed from the SSF method. The subspace fitting approach was firstly presented by [2] and it was formalized by [3] which is written as,

$\lfloor\hat{A}, \hat{T}\rfloor=\arg \min _{A, T}\|M-A(\eta) T\|_{F}^{2}$

In this equation, $M$ is a $m \times q$ matrix that may be obtained from the given data. The $m \times p$ matrix $A$ is calculated from $\eta$ and $T$ is the $p \times q$ matrix. The parameter estimation vector

$\eta$ is the argument of $\hat{A}$. The matrix $M$ and dimension of it can be chosen in the different ways to give different estimation. The fitting problem is separated with the help of $A$ and $T$

[Capon]. Now putting $\hat{A}=A * M$ in to the above equation, we may get the new equation,

$$
\hat{A}=\arg \max _{A} T_{r}\left\{P_{A} M M^{*}\right\}
$$

Where, $P_{A}=A(A * A)^{-1} A *$ is the projection matrix which is used to projects on the column space of $A$. Different algorithms and methods are explore like Deterministic Maximum Likelihood (DML), Beamforming, MUSIC, Multi dimensional MUSIC(MD-MUSIC), ESPRIT are proposed based on subspace fitting framework.

Alternating projection is used to transform the multivariate non-linear maximization problem in to a sequence of 1-d maximization. [6] introduced a new algorithm by maximizing the likelihood function given below:

$$
L=-K d \log \sigma^{2}-\frac{1}{\sigma^{2}} \sum_{l=0}^{k-1}\left|x_{i}(l)-A(\theta) S_{i}\right|^{2}
$$

This method is known as alternating projection method. The flow chart and basic step follows in this method are given below. In this, firstly one dimensional projection is find out that is further used to maximize L.

\section{ESPRIT (Estimation of Signal Parameters Via Rotational Invariance Techniques)}

[Roy and Kailath] [1] proposed a new algorithm named ESPRIT for DOA estimation. Array doublets are formed by N/2 pairs which further form a displacement vector. The starting two elements of the doublet are separated and grouped to make two $\mathrm{N} / 2$ sub arrays. The vectors $\mathrm{x}$ and $\mathrm{y}$ are the data vectors corresponding to each of the sub arrays. The output of the sub arrays $z$ and $y$ can be expressed as:

$$
\begin{aligned}
& x_{k}[n]=\sum_{i=0}^{r-1} s_{i}[n] a_{k}\left(\theta_{i}\right)+v_{k}^{(x)}[n], \\
& y_{k}[n]=\sum_{i=1}^{r-1} s_{i}[n] e^{j 2 \pi \delta \sin \theta_{\mathrm{k}}} a_{k}\left(\theta_{i}\right)+v_{k}^{(y)}[n],
\end{aligned}
$$

Where similar notation has been used and $\delta$ is displacement magnitude in wavelengths. The estimated angle by ESPRIT algorithm relative to the displacement vector. The sub arrays, $\mathrm{x}$ and $y$, output is given in matrix form is:

$x_{n}=A s_{n}+v_{n}^{x}$
$y_{n}=A \phi s_{n}+v_{n}^{y}$

The matrix $\phi$ is a diagonal $r \times r$, matrix having diagonal elements are $\left\{\exp \left(j 2 \pi \delta \sin \theta_{0}\right), \exp \left(j 2 \pi \delta \sin \theta_{1}\right), \ldots, \exp \left(j 2 \pi \delta \sin \theta_{r-1}\right)\right\}$. The phase delay may be represented by the complex exponentials between the $r$ signals and doublet pair. The data vectors may be concatenated from sub arrays to make a single $2 \mathrm{~N}-2$ data vector, like,

$z_{n}=\left\lfloor\begin{array}{l}x_{n} \\ y_{n}\end{array}\right\rfloor=A_{b} S_{n}$ 


$$
A_{b}=\left[\begin{array}{c}
A \\
A \phi
\end{array}\right], V_{n}=\left[\begin{array}{c}
v_{n}^{(x)} \\
v_{n}^{(y)}
\end{array}\right]
$$

The columns of $A_{b}$ occupy the signal subspace of the new array. Let $\mathrm{V}_{\mathrm{s}}$ be the column matrix depending upon the signal subspace as $\mathrm{Z}_{\mathrm{n}}, A_{b}$ and $V_{s}$ are related with $r \times r$ transformation $\mathrm{T}$ is written as:

$V_{s}=A_{b} T$,

and can portioned as follows:

$V_{s}=\left\lfloor\begin{array}{c}E_{x} \\ E_{y}\end{array}\right\rfloor=\left\lfloor\begin{array}{c}A T \\ A \phi T\end{array}\right\rfloor$

From this step, the range of $E_{x}, E_{y}$ and A will be equal as $E_{x}, E_{y}$ have the same range, the rank $\mathrm{r}$ matrix $E_{x y}$ as follows:

$E_{x y}=\left[\begin{array}{ll}E_{x} & E_{y}\end{array}\right]$

To find $r \times 2 r$ rank $r$ matrix having null space of $E_{x y}$ to form matrix $\mathrm{F}$, and is written as:

$$
\left[\begin{array}{ll}
E_{x} & E_{y}
\end{array}\right] F=E_{x} F_{x}+E_{y} F_{y}=A T F_{x}+A \phi T F_{y}
$$

Assume $\psi$ is:

$$
\psi=-F_{x}\left[F_{y}\right]^{-1}
$$

Reshuffling the above equations gives:

$$
E_{x} \psi=E_{y}
$$

Now by substituting we get the results:

$$
A T \psi=A \phi T \Rightarrow A T \psi T^{-1}=A \phi \Rightarrow T \psi T^{-1}=\phi
$$

The given equations means that the Eigen values of $\psi$ is same as diagonal elements of $\phi$. Once the Eigen values, $\lambda$, of $\phi$ have been calculated, the angle of arrival is calculated as:

$$
\lambda_{k}=e^{j 2 \pi \delta \sin \theta_{k}}
$$

$$
\theta_{k}=\arcsin \left(\frac{\arg \left(\lambda_{k}\right)}{2 \pi \delta}\right)
$$

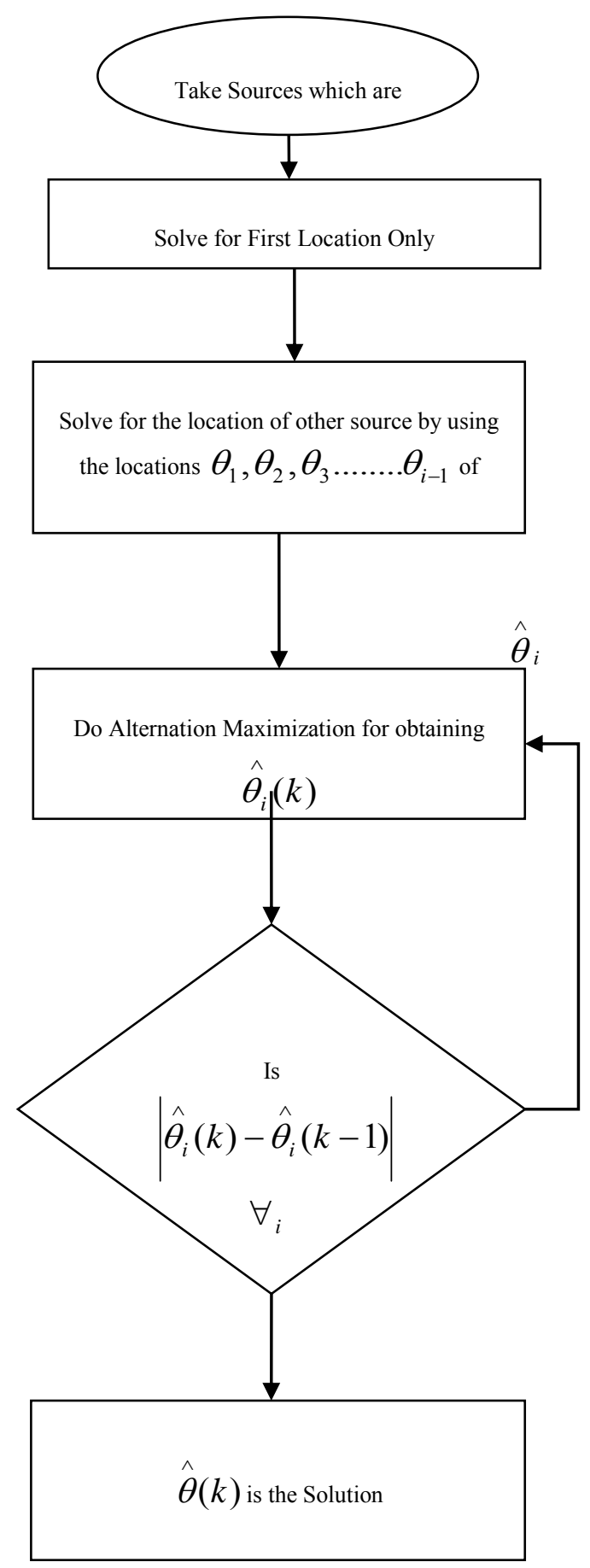

Figure 1: Flow chart of AP-SSF algorithm 


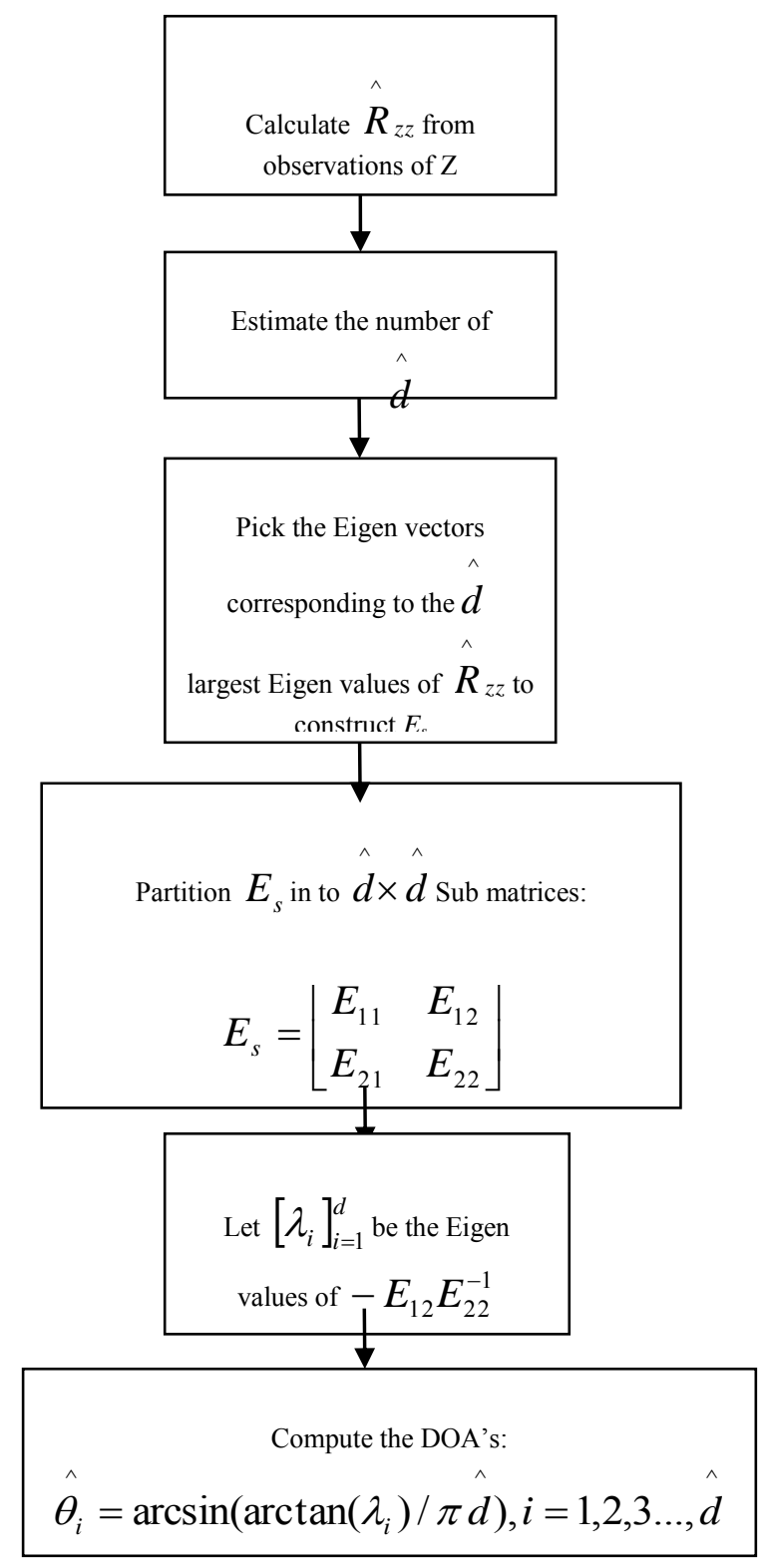

Figure 2: ESPRIT Algorithm Flow Chart

If $\mathrm{A}$ be the full rank matrix, then the Eigen values of the matrix $\psi$ are the diagonal elements of $\phi$ and the Eigen vectors of $\psi$ are the columns of the $T$. in practical, the signal subspace is not known exactly, the only estimate is from sample covariance matrix $R_{x x}$ or from a sub space tracking algorithm. There for, $E_{x} \psi=E_{y}$, will not be exactly satisfied and we will have to resort to a least square solution to computes $\psi$. The least square process assumes that the columns in $E_{x}$ are known exactly whereas the data in $E_{y}$ is noisy. If the assumptions is made that $E_{x}$ and $E_{y}$ are equally noisy, the total least square criteria is used to solve, which gives better results.

The above algorithms are studied in detailed and the comparison is given here for one, two, three, four and five signals.

Table 1: Estimated Signal Directions at receiving antenna array when number of elements $=10$, number of samples $=100$ and $S N R=20 \mathrm{db}$

\begin{tabular}{|ll|l|}
\hline \multicolumn{2}{|c|}{ Algorithm } & \multicolumn{1}{c|}{$\begin{array}{c}\text { Signal Directions } \\
\left(40^{\circ}\right)\end{array}$} \\
\hline $\begin{array}{l}\text { Alternating } \\
\text { ML }\end{array}$ & Projection & 40.0120 \\
\hline $\begin{array}{l}\text { Alternating } \\
\text { SSF }\end{array}$ & Projection & 16.0040 \\
\hline ESPRIT & 40.0177 \\
\hline
\end{tabular}

The above table gives the signal estimation for single source that is coming from the direction $40^{\circ}$ and the three algorithms the signal directions. The signal estimated from the APSSF gives wrong signal estimation while as comparison to the AL-ML, the ESPRIT algorithm gives better accuracy.

Table 2: Estimated Signal Directions at receiving antenna array when number of elements $=10$, number of samples $=100$ and $S N R=20 \mathrm{db}$

\begin{tabular}{|c|c|c|}
\hline Algorithm & $\begin{array}{c}\text { Signal } \\
\text { Directions } \\
\left(-10^{\circ}\right)\end{array}$ & $\begin{array}{c}\text { Signal } \\
\text { Directions } \\
\left(-20^{\circ}\right)\end{array}$ \\
\hline $\begin{array}{c}\text { Alternating } \\
\text { Projection ML }\end{array}$ & -9.8600 & -19.9680 \\
\hline $\begin{array}{c}\text { Alternating } \\
\text { Projection SSF }\end{array}$ & -9.9480 & -19.912 \\
\hline ESPRIT & -10.0312 & -19.9641 \\
\hline
\end{tabular}

The above table gives the description of the estimated signal when two signals from the directions $-10^{\circ}$ and $-20^{\circ}$ are coming at the receiver side and the number of antenna elements are take as 10, number of samples are 100 and SNR is $20 \mathrm{~dB}$. 
Table 3: Estimated Signal Directions at receiving antenna array when number of elements $=10$, number of samples=100 and $\mathrm{SNR}=\mathbf{2 0 \mathrm { db }}$

\begin{tabular}{|l|l|l|l|}
\hline Algorithm & $\begin{array}{l}\text { Signal } \\
\text { Direction } \\
\text { s } \\
\left(-10^{\circ}\right)\end{array}$ & $\begin{array}{l}\text { Signal } \\
\text { Direction } \\
\text { s } \\
\left(-20^{\circ}\right)\end{array}$ & $\begin{array}{l}\text { Signal } \\
\text { Direction } \\
\text { s } \\
\left(-30^{\circ}\right)\end{array}$ \\
\hline $\begin{array}{l}\text { Alternatin } \\
\text { g } \\
\text { Projection } \\
\text { ML }\end{array}$ & -3.3820 & -26.0600 & -30.0680 \\
\hline $\begin{array}{l}\text { Alternatin } \\
\text { g } \\
\text { Projection } \\
\text { SSF }\end{array}$ & -7.0800 & -21.4840 & -30.4840 \\
\hline ESPRIT & -10.0677 & -20.4922 & -30.1516 \\
\hline
\end{tabular}

The above table gives the description of the estimated signal when three signals from the directions $-10^{\circ},-20^{\circ}$ and $-30^{\circ}$ are coming at the receiver side and the number of antenna elements are take as 10, number of samples are 100 and SNR is $20 \mathrm{~dB}$.

Table 4: Estimated Signal Directions at receiving antenna array when number of elements $=10$, number of samples $=100$ and $S N R=20 \mathrm{db}$

\begin{tabular}{|l|c|c|c|}
\hline Algorithm & $\begin{array}{c}\text { Signal } \\
\text { Directions } \\
\left(40^{\circ}\right)\end{array}$ & $\begin{array}{c}\text { Signal } \\
\text { Directions } \\
\left(50^{\circ}\right)\end{array}$ & $\begin{array}{c}\text { Signal } \\
\text { Directions } \\
\left(70^{\circ}\right)\end{array}$ \\
\hline $\begin{array}{l}\text { Alternating } \\
\text { Projection } \\
\text { ML }\end{array}$ & 40.0120 & 50.0080 & 70.0040 \\
\hline $\begin{array}{l}\text { Alternating } \\
\text { Projection } \\
\text { SSF }\end{array}$ & 16.0040 & 66.0040 & 70.0040 \\
\hline ESPRIT & 40.0177 & 50.0052 & 69.9985 \\
\hline
\end{tabular}

The above table gives the Discription of the estimated signal when three signals from the directions $40^{\circ}, 50^{\circ}$ and $70^{\circ}$ are coming at the receiver side and the number of antenna elements are take as 10, number of samples are 100 and SNR is $20 \mathrm{~dB}$.

Table 5: Estimated Signal Directions at receiving antenna array when number of elements $=10$, number of samples $=64$ and $S N R=20 \mathrm{db}$

\begin{tabular}{|c|c|c|c|c|}
\hline $\begin{array}{l}\text { Algor } \\
\text { ithm }\end{array}$ & $\begin{array}{l}\text { Signal } \\
\text { Directi } \\
\text { ons } \\
\left(60^{\circ}\right)\end{array}$ & $\begin{array}{l}\text { Signal } \\
\text { Directio } \\
\text { ns } \\
\left(80^{\circ}\right)\end{array}$ & $\begin{array}{l}\text { Signa } \\
\text { l } \\
\text { Direc } \\
\text { tions } \\
\left(90^{\circ}\right. \\
)\end{array}$ & $\begin{array}{l}\text { Signal } \\
\text { Directions } \\
\left(100^{\circ}\right)\end{array}$ \\
\hline $\begin{array}{l}\text { Alter } \\
\text { natin } \\
\text { g } \\
\text { Proje } \\
\text { ction } \\
\text { ML }\end{array}$ & $\begin{array}{l}54.012 \\
0\end{array}$ & 75.9960 & $\begin{array}{l}92.99 \\
20\end{array}$ & 99.9920 \\
\hline $\begin{array}{l}\text { Alter } \\
\text { natin } \\
\text { g } \\
\text { Proje } \\
\text { ction } \\
\text { SSF } \\
\end{array}$ & $\begin{array}{l}60.004 \\
0\end{array}$ & 76.0000 & $\begin{array}{l}87.00 \\
00\end{array}$ & 100.0080 \\
\hline $\begin{array}{l}\text { ESP } \\
\text { RIT }\end{array}$ & $\begin{array}{l}60.013 \\
1\end{array}$ & 80.0166 & $\begin{array}{l}89.98 \\
50 \\
\end{array}$ & 100.0023 \\
\hline
\end{tabular}

In the above table, the simulations are performed for the four signals when the number of array elements at the receiving antenna is considered 10, the samples taken at the receiving antenna are 64 and the signal to noise ratio at is $20 \mathrm{~dB}$.

Table 6: Estimated Signal Directions at receiving antenna array when number of elements $=10$, number of samples=100 and $\mathrm{SNR}=\mathbf{2 0 \mathrm { db }}$

\begin{tabular}{|l|l|l|l|l|}
\hline $\begin{array}{l}\text { Algori } \\
\text { thm }\end{array}$ & $\begin{array}{l}\text { Signal } \\
\text { Directio } \\
\text { ns } \\
\left(60^{\circ}\right)\end{array}$ & $\begin{array}{l}\text { Signal } \\
\text { Directi } \\
\text { ons } \\
\left(80^{\circ}\right)\end{array}$ & $\begin{array}{l}\text { Signal } \\
\text { Directio } \\
\text { ns } \\
\left(90^{\circ}\right)\end{array}$ & $\begin{array}{l}\text { Signal } \\
\text { Direction } \\
\text { s } \\
\left(100^{\circ}\right)\end{array}$ \\
\hline $\begin{array}{l}\text { Altern } \\
\text { ating } \\
\text { Projec } \\
\text { tion } \\
\text { ML }\end{array}$ & 54.0040 & $\begin{array}{l}77.980 \\
0\end{array}$ & 94.0200 & 99.9920 \\
\hline $\begin{array}{l}\text { Altern } \\
\text { ating } \\
\text { Projec } \\
\text { tion } \\
\text { SSF }\end{array}$ & 60.0080 & $\begin{array}{l}77.992 \\
0\end{array}$ & 89.0080 & 99.9880 \\
\hline $\begin{array}{l}\text { ESPR } \\
\text { IT }\end{array}$ & 60.0067 & $\begin{array}{l}79.989 \\
1\end{array}$ & 90.0006 & 99.9832 \\
\hline
\end{tabular}


In the above table, the simulations are performed for the four signals when the number of array elements at the receiving antenna is considered 10, the samples taken at the receiving antenna are 100 and the signal to noise ratio at is $20 \mathrm{~dB}$. When we increase the number of snapshots, the accuracy of the algorithms is increased and the incoming signal direction is measured more accurate.

Table 7: Estimated Signal Directions at receiving antenna array when number of elements $=10$, number of samples $=100$ and $S N R=20 \mathrm{db}$

\begin{tabular}{|l|l|l|l|l|l|}
\hline $\begin{array}{l}\text { Algori } \\
\text { thm }\end{array}$ & $\begin{array}{l}\text { Signa } \\
\mathbf{l} \\
\text { Direc } \\
\text { tions } \\
\left(40^{\circ}\right)\end{array}$ & $\begin{array}{l}\text { Signa } \\
\mathbf{l} \\
\text { Direc } \\
\text { tions } \\
\left(50^{\circ}\right.\end{array}$ & $\begin{array}{l}\text { Signa } \\
\mathbf{l} \\
\text { Direc } \\
\text { tions } \\
\left(70^{\circ}\right.\end{array}$ & $\begin{array}{l}\text { Signa } \\
\mathbf{l} \\
\text { Direc } \\
\text { tions } \\
\left(90^{\circ}\right.\end{array}$ & $\begin{array}{l}\text { Signa } \\
\mathbf{l} \\
\text { Direc } \\
\text { tions } \\
\left(\begin{array}{l} \\
\left.120^{\circ}\right)\end{array}\right.\end{array}$ \\
\hline $\begin{array}{l}\text { Altern } \\
\text { ating } \\
\text { Projec } \\
\text { tion } \\
\text { ML }\end{array}$ & 36.02 & 42.01 & 77.36 & $\begin{array}{l}104.9 \\
920\end{array}$ & $\begin{array}{l}120.2 \\
400\end{array}$ \\
\hline $\begin{array}{l}\text { Altern } \\
\text { ating } \\
\text { Projec } \\
\text { tion } \\
\text { SSF }\end{array}$ & 39.99 & 47.99 & 64.02 & $\begin{array}{l}85.98 \\
80\end{array}$ & $\begin{array}{l}119.9 \\
960\end{array}$ \\
\hline $\begin{array}{l}\text { ESPRI } \\
\text { T }\end{array}$ & 40.02 & 49.99 & 70.00 & $\begin{array}{l}89.99 \\
77\end{array}$ & 120.0 \\
\hline
\end{tabular}

In the above table, the simulations are performed for the five signals when the number of array elements at the receiving antenna is considered 10, the samples taken at the receiving antenna are 100 and the signal to noise ratio at is $20 \mathrm{~dB}$.

Table 8: Estimated Signal Directions at receiving antenna array when number of elements $=100$, number of samples $=100$ and $S N R=20 \mathrm{db}$

\begin{tabular}{|l|l|l|l|l|}
\hline $\begin{array}{l}\text { Algorith } \\
\mathbf{m}\end{array}$ & $\begin{array}{l}\text { Signal } \\
\text { Directi } \\
\text { ons } \\
\left(60^{\circ}\right)\end{array}$ & $\begin{array}{l}\text { Signal } \\
\text { Directi } \\
\text { ons } \\
\left(80^{\circ}\right)\end{array}$ & $\begin{array}{l}\text { Signal } \\
\text { Directi } \\
\text { ons } \\
\left(90^{\circ}\right)\end{array}$ & $\begin{array}{l}\text { Signal } \\
\text { Directi } \\
\text { ons } \\
\left(100^{\circ}\right)\end{array}$ \\
\hline $\begin{array}{l}\text { Alternat } \\
\text { ing } \\
\text { Projecti }\end{array}$ & 54.0000 & 80.0000 & 100.000 & $\begin{array}{l}100.016 \\
0\end{array}$ \\
\hline
\end{tabular}

\begin{tabular}{|l|l|l|l|l|}
\hline on ML & & & & \\
\hline $\begin{array}{l}\text { Alternat } \\
\text { ing } \\
\text { Projecti } \\
\text { on SSF }\end{array}$ & 54.0000 & 54.0000 & 64.0000 & $\begin{array}{l}100.000 \\
0\end{array}$ \\
\hline ESPRIT & 60.0009 & 80.0007 & 89.9998 & 99.9988 \\
\hline
\end{tabular}

In the above table, the simulations are performed for the four signals when the number of array elements at the receiving antenna is considered 100, the samples taken at the receiving antenna are 100 and the signal to noise ratio at is $20 \mathrm{~dB}$.

Table 9: Estimated Signal Directions at receiving antenna array when number of elements $=5$, number of samples $=100$ and $S N R=20 \mathrm{db}$

\begin{tabular}{|l|l|l|l|l|}
\hline $\begin{array}{l}\text { Algorith } \\
\text { m }\end{array}$ & $\begin{array}{l}\text { Signal } \\
\text { Directi } \\
\text { ons } \\
\left(60^{\circ}\right)\end{array}$ & $\begin{array}{l}\text { Signal } \\
\text { Directi } \\
\text { ons } \\
\left(80^{\circ}\right)\end{array}$ & $\begin{array}{l}\text { Signal } \\
\text { Directi } \\
\text { ons } \\
\left(90^{\circ}\right)\end{array}$ & $\begin{array}{l}\text { Signal } \\
\text { Directi } \\
\text { ons } \\
\left(100^{\circ}\right)\end{array}$ \\
\hline $\begin{array}{l}\text { Alternat } \\
\text { ing } \\
\text { Projecti } \\
\text { on ML }\end{array}$ & 23.9640 & 33.9960 & 95.5400 & 99.9640 \\
\hline $\begin{array}{l}\text { Alternat } \\
\text { ing } \\
\text { Projecti } \\
\text { on SSF }\end{array}$ & 60.0320 & 73.9520 & 90.6720 & 99.8840 \\
\hline ESPRIT & 60.0550 & 79.7319 & 90.0373 & 100.034 \\
\hline
\end{tabular}

In the above table, the simulations are performed for the four signals when the number of array elements at the receiving antenna is considered 5, the samples taken at the receiving antenna are 100 and the signal to noise ratio at is $20 \mathrm{~dB}$.

5. Effect of increasing the number of elements, number of samples and SNR at antenna array

We studied the detailed comparison of the three algorithms when we increase the number of antenna elements at the receiver array, number of samples taken at the receiver side for signal estimation and by increasing the signal to noise ratio at the receiver side. The signals taken are 
two here form $45^{\circ}$ and $60^{\circ}$ directions respectively. The estimation through ESPRIT algorithm gives good results in all conditions when we increase the antenna elements, spacing between the antenna elements and SNR level.

Table 10: Estimated Signal Directions at receiving antenna array when numbers of elements are increasing keeping other parameters fixed.

\begin{tabular}{|c|c|c|c|c|c|c|c|c|}
\hline & \multicolumn{2}{|c|}{ 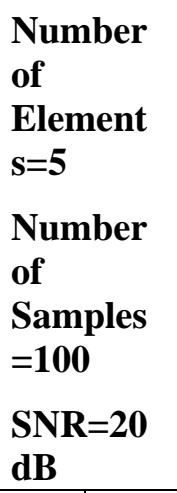 } & \multicolumn{2}{|c|}{$\begin{array}{l}\begin{array}{l}\text { Number } \\
\text { of } \\
\text { Element } \\
s=10\end{array} \\
\text { Number } \\
\text { of } \\
\text { Samples } \\
=100 \\
\text { SNR=20 } \\
\text { dB }\end{array}$} & \multicolumn{2}{|c|}{$\begin{array}{l}\begin{array}{l}\text { Number } \\
\text { of } \\
\text { Element } \\
\text { s=20 }\end{array} \\
\text { Number } \\
\text { of } \\
\text { Samples } \\
=100 \\
\text { SNR=20 } \\
\text { dB }\end{array}$} & \multicolumn{2}{|c|}{$\begin{array}{l}\begin{array}{l}\text { Number } \\
\text { of }\end{array} \\
\text { Element } \\
\text { s=100 } \\
\text { Number } \\
\text { of } \\
\text { Samples } \\
=100 \\
\text { SNR=20 } \\
\text { dB }\end{array}$} \\
\hline & $\begin{array}{l}\text { Sig } \\
\text { nal } \\
\text { Dir } \\
\text { ect } \\
\text { ion } \\
\text { s } \\
\left(45^{\circ}\right. \\
\\
\end{array}$ & $\begin{array}{l}\text { Sig } \\
\text { nal } \\
\text { Dir } \\
\text { ect } \\
\text { ion } \\
\text { s } \\
(1 \\
60^{\circ} \\
) \\
\end{array}$ & $\begin{array}{l}\text { Sig } \\
\text { nal } \\
\text { Dir } \\
\text { ect } \\
\text { ion } \\
\text { s } \\
\left(45^{\circ}\right. \\
\\
\end{array}$ & $\begin{array}{l}\text { Sig } \\
\text { nal } \\
\text { Dir } \\
\text { ect } \\
\text { ion } \\
\text { s } \\
60^{\circ} \\
) \\
\end{array}$ & $\begin{array}{l}\text { Sig } \\
\text { nal } \\
\text { Dir } \\
\text { ect } \\
\text { ion } \\
\text { s } \\
\left(45^{\circ}\right. \\
\\
\end{array}$ & $\begin{array}{l}\text { Sig } \\
\text { nal } \\
\text { Dir } \\
\text { ect } \\
\text { ion } \\
\text { s } \\
( \\
60^{\circ} \\
) \\
\end{array}$ & $\begin{array}{l}\text { Sig } \\
\text { nal } \\
\text { Dir } \\
\text { ect } \\
\text { ion } \\
\text { s } \\
\left(45^{\circ}\right. \\
) \\
\end{array}$ & $\begin{array}{l}\text { Sig } \\
\text { nal } \\
\text { Dir } \\
\text { ect } \\
\text { ion } \\
\text { s } \\
60^{\circ} \\
{ }^{\circ} \\
\end{array}$ \\
\hline $\begin{array}{l}\text { Alt } \\
\text { ern } \\
\text { ati } \\
\text { ng } \\
\text { Pro } \\
\text { ject } \\
\text { ion } \\
\text { ML }\end{array}$ & $\begin{array}{l}45 . \\
06 \\
00\end{array}$ & $\begin{array}{l}60 \\
03 \\
60\end{array}$ & $\begin{array}{l}45 . \\
01 \\
20\end{array}$ & $\begin{array}{l}59 . \\
99 \\
60\end{array}$ & $\begin{array}{l}45 . \\
00 \\
00\end{array}$ & $\begin{array}{l}60 \\
00 \\
00\end{array}$ & $\begin{array}{l}45 . \\
00 \\
00\end{array}$ & $\begin{array}{l}60 . \\
00 \\
00\end{array}$ \\
\hline $\begin{array}{l}\text { Alt } \\
\text { ern } \\
\text { ati } \\
\text { ng } \\
\text { Pro } \\
\text { ject } \\
\text { ion } \\
\text { SS } \\
\text { F } \\
\end{array}$ & $\begin{array}{l}45 . \\
05 \\
20\end{array}$ & $\begin{array}{l}60 . \\
03 \\
20\end{array}$ & $\begin{array}{l}01 \\
01 \\
20\end{array}$ & $\begin{array}{l}59 . \\
99 \\
60\end{array}$ & $\begin{array}{l}45 . \\
00 \\
00\end{array}$ & $\begin{array}{l}60 . \\
00 \\
00\end{array}$ & $\begin{array}{l}45 . \\
00 \\
00\end{array}$ & $\begin{array}{l}60 . \\
00 \\
00\end{array}$ \\
\hline $\begin{array}{l}\text { ES } \\
\text { PR } \\
\text { IT }\end{array}$ & $\begin{array}{l}45 . \\
06 \\
26\end{array}$ & $\begin{array}{l}60 . \\
00 \\
99\end{array}$ & $\begin{array}{l}45 . \\
01 \\
77\end{array}$ & $\begin{array}{l}59 . \\
99 \\
68\end{array}$ & $\begin{array}{l}45 . \\
00 \\
00\end{array}$ & $\begin{array}{l}60 . \\
00 \\
00\end{array}$ & $\begin{array}{l}45 . \\
00 \\
00\end{array}$ & $\begin{array}{l}60 . \\
00 \\
00\end{array}$ \\
\hline
\end{tabular}

In the above table, the simulations are performed for the two signals incoming from the direction $45^{\circ}$ and $60^{\circ}$ when the number of array elements at the receiving antenna is increasing from 5, 10, 20, 100, the samples taken at the receiving antenna are 100 and the signal to noise ratio at is $20 \mathrm{~dB}$. From the above table it is clear that when we increase the number of samples the accuracy of the estimation is increased and the ESPRIT algorithm gives better results.

Table 11: Estimated Signal Directions at receiving antenna array when number of samples is increasing keeping other parameters fixed.

\begin{tabular}{|c|c|c|c|c|c|c|c|c|}
\hline & \multicolumn{2}{|c|}{$\begin{array}{l}\begin{array}{l}\text { Number } \\
\text { of }\end{array} \\
\text { Element } \\
s=10 \\
\text { Number } \\
\text { of } \\
\text { Samples } \\
=1 \\
\text { SNR=20 } \\
\text { dB }\end{array}$} & \multicolumn{2}{|c|}{$\begin{array}{l}\text { Number } \\
\text { of } \\
\text { Element } \\
s=10 \\
\text { Number } \\
\text { of } \\
\text { Samples } \\
=10 \\
\text { SNR=20 } \\
\text { dB }\end{array}$} & \multicolumn{2}{|c|}{$\begin{array}{l}\begin{array}{l}\text { Number } \\
\text { of } \\
\text { Element } \\
\text { s=10 }\end{array} \\
\text { Number } \\
\text { of } \\
\text { Samples } \\
=20 \\
\text { SNR=20 } \\
\text { dB }\end{array}$} & \multicolumn{2}{|c|}{$\begin{array}{l}\begin{array}{l}\text { Number } \\
\text { of } \\
\text { Element }\end{array} \\
\text { s=10 } \\
\text { Number } \\
\text { of } \\
\text { Samples } \\
=100 \\
\text { SNR=20 } \\
\text { dB }\end{array}$} \\
\hline & $\begin{array}{l}\text { Sig } \\
\text { nal } \\
\text { Dir } \\
\text { ect } \\
\text { ion } \\
\text { s } \\
( \\
45^{\circ} \\
\end{array}$ & $\begin{array}{l}\text { Sig } \\
\text { nal } \\
\text { Dir } \\
\text { ect } \\
\text { ion } \\
\text { s } \\
( \\
60^{\circ} \\
) \\
\end{array}$ & $\begin{array}{l}\text { Sig } \\
\text { nal } \\
\text { Dir } \\
\text { ect } \\
\text { ion } \\
\text { s } \\
\left(45^{\circ}\right. \\
{ }^{\circ} \\
\end{array}$ & $\begin{array}{l}\text { Sig } \\
\text { nal } \\
\text { Dir } \\
\text { ect } \\
\text { ion } \\
\text { s } \\
( \\
60^{\circ} \\
) \\
\end{array}$ & $\begin{array}{l}\text { Sig } \\
\text { nal } \\
\text { Dir } \\
\text { ect } \\
\text { ion } \\
\text { s } \\
( \\
45^{\circ} \\
) \\
\end{array}$ & $\begin{array}{l}\text { Sig } \\
\text { nal } \\
\text { Dir } \\
\text { ect } \\
\text { ion } \\
\text { s } \\
( \\
60^{\circ} \\
) \\
\end{array}$ & $\begin{array}{l}\text { Sig } \\
\text { nal } \\
\text { Dir } \\
\text { ect } \\
\text { ion } \\
\text { s } \\
( \\
45^{\circ} \\
) \\
\end{array}$ & $\begin{array}{l}\text { Sig } \\
\text { nal } \\
\text { Dir } \\
\text { ect } \\
\text { ion } \\
\text { s } \\
60^{\circ} \\
{ }^{\circ} \\
\end{array}$ \\
\hline $\begin{array}{l}\text { Alt } \\
\text { ern } \\
\text { ati } \\
\text { ng } \\
\text { Pro } \\
\text { ject } \\
\text { ion } \\
\text { ML }\end{array}$ & $\begin{array}{l}45 \\
04 \\
80\end{array}$ & $\begin{array}{l}59 . \\
92 \\
40\end{array}$ & $\begin{array}{l}44 . \\
98 \\
40\end{array}$ & $\begin{array}{l}60 . \\
01 \\
60\end{array}$ & $\begin{array}{l}45 \\
00 \\
00\end{array}$ & $\begin{array}{l}60 . \\
00 \\
80\end{array}$ & $\begin{array}{l}45 \\
01 \\
20\end{array}$ & $\begin{array}{l}59 . \\
99 \\
60\end{array}$ \\
\hline $\begin{array}{l}\text { Alt } \\
\text { ern } \\
\text { ati } \\
\text { ng } \\
\text { Pro } \\
\text { ject } \\
\text { ion } \\
\text { SS }\end{array}$ & $\begin{array}{l}46 . \\
22 \\
80\end{array}$ & $\begin{array}{l}65 \\
16 \\
80\end{array}$ & $\begin{array}{l}44 . \\
97 \\
60\end{array}$ & $\begin{array}{l}60 . \\
01 \\
60\end{array}$ & $\begin{array}{l}45 . \\
00 \\
00\end{array}$ & $\begin{array}{l}60 . \\
01 \\
20\end{array}$ & $\begin{array}{l}45 \\
01 \\
20\end{array}$ & $\begin{array}{l}59 . \\
99 \\
60\end{array}$ \\
\hline
\end{tabular}




\begin{tabular}{|l|l|l|l|l|l|l|l|l|}
\hline F & & & & & & & & \\
\hline ES & 49. & 99. & 44. & 60. & 44. & 60. & 45. & 60. \\
PR & 37 & 24 & 95 & 02 & 99 & 02 & 00 & 00 \\
IT & 30 & 65 & 12 & 40 & 57 & 01 & 00 & 00 \\
\hline
\end{tabular}

In the above table, the simulations are performed for the two signals incoming from the direction $45^{\circ}$ and $60^{\circ}$ when the number of samples taken at the receiver side is increasing from $1,10,20,100$, the number of antenna elements are fixed as 10 and the signal to noise ratio at is $20 \mathrm{~dB}$. From the above table it is clear that when we increase the number of antenna elements the accuracy of the estimation is increased.

Table 12: Estimated Signal Directions at receiving antenna array when SNR are increasing keeping other parameters fixed.

\begin{tabular}{|c|c|c|c|c|c|c|c|c|}
\hline \multirow[t]{2}{*}{$\begin{array}{l}\text { Alg } \\
\text { orit } \\
\text { hm }\end{array}$} & \multicolumn{2}{|c|}{$\begin{array}{l}\begin{array}{l}\text { Number } \\
\text { of } \\
\text { Elements } \\
=10\end{array} \\
\text { Number } \\
\text { of } \\
\text { Samples= } \\
100 \\
\text { SNR=1d } \\
\text { B }\end{array}$} & \multicolumn{2}{|c|}{$\begin{array}{l}\begin{array}{l}\text { Number } \\
\text { of }\end{array} \\
\text { Elements } \\
=10 \\
\text { Number } \\
\text { of } \\
\text { Samples= } \\
100 \\
\text { SNR=10d } \\
\text { B }\end{array}$} & \multicolumn{2}{|c|}{$\begin{array}{l}\begin{array}{l}\text { Number } \\
\text { of }\end{array} \\
\text { Elements } \\
=10 \\
\text { Number } \\
\text { of } \\
\text { Samples= } \\
100 \\
\text { SNR=20d } \\
\text { B }\end{array}$} & \multicolumn{2}{|c|}{ 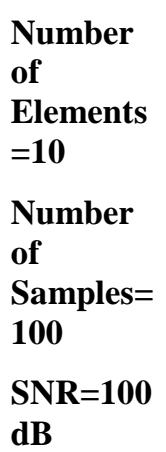 } \\
\hline & $\begin{array}{l}\text { Sig } \\
\text { nal } \\
\text { Dir } \\
\text { ecti } \\
\text { ons } \\
( \\
45^{\circ}\end{array}$ & $\begin{array}{l}\text { Sig } \\
\text { nal } \\
\text { Dir } \\
\text { ecti } \\
\text { ons } \\
( \\
60^{\circ} \\
)^{\circ}\end{array}$ & $\begin{array}{l}\text { nal } \\
\text { Dir } \\
\text { ecti } \\
\text { ons } \\
( \\
45^{\circ} \\
)\end{array}$ & $\begin{array}{l}\text { Sig } \\
\text { nal } \\
\text { Dir } \\
\text { ecti } \\
\text { ons } \\
( \\
60^{\circ} \\
)\end{array}$ & $\begin{array}{l}\text { Sig } \\
\text { nal } \\
\text { Dir } \\
\text { ecti } \\
\text { ons } \\
( \\
45^{\circ} \\
)\end{array}$ & $\begin{array}{l}\text { Sig } \\
\text { nal } \\
\text { Dir } \\
\text { ecti } \\
\text { ons } \\
( \\
60^{\circ} \\
)\end{array}$ & 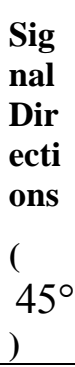 & $\begin{array}{l}\text { Sig } \\
\text { nal } \\
\text { Dir } \\
\text { ecti } \\
\text { ons } \\
( \\
60^{\circ} \\
)^{\circ}\end{array}$ \\
\hline $\begin{array}{l}\text { ting } \\
\text { Pro } \\
\text { ject } \\
\text { ion }\end{array}$ & $\begin{array}{l}17 \\
0\end{array}$ & $\begin{array}{l}59 . \\
976 \\
0\end{array}$ & 0 & $\begin{array}{l}59 . \\
992 \\
0\end{array}$ & 012 & $\begin{array}{l}59 . \\
996 \\
0\end{array}$ & & $\begin{array}{l}60 . \\
000 \\
0\end{array}$ \\
\hline $\begin{array}{l}\text { Alte } \\
\text { rna } \\
\text { ting } \\
\text { Pro } \\
\text { ject } \\
\text { ion }\end{array}$ & $\begin{array}{l}45 . \\
168 \\
0\end{array}$ & $\begin{array}{l}59 . \\
972 \\
0\end{array}$ & $\begin{array}{l}048 \\
0\end{array}$ & $\begin{array}{l}59 . \\
984 \\
0\end{array}$ & $\begin{array}{l}45 . \\
012 \\
0\end{array}$ & $\begin{array}{l}59 . \\
996 \\
0\end{array}$ & & $\begin{array}{l}60 . \\
000 \\
0\end{array}$ \\
\hline $\begin{array}{l}\text { ES } \\
\text { PRI }\end{array}$ & $\begin{array}{l}45 . \\
124\end{array}$ & $\begin{array}{l}59 . \\
974\end{array}$ & & 994 & $\begin{array}{l}45 . \\
000\end{array}$ & 000 & 000 & $\begin{array}{l}60 . \\
000 \\
\end{array}$ \\
\hline
\end{tabular}

\begin{tabular}{|l|l|l|l|l|l|l|l|l|}
\hline T & 6 & 8 & 6 & 0 & 0 & 0 & 0 & 0 \\
\hline
\end{tabular}

In the above table, the simulations are performed for the two signals incoming from the direction $45^{\circ}$ and $60^{\circ}$ when the SNR at the receiver side is increasing from $1,10,20,100$, the number of antenna elements are fixed as 10 and the samples taken are 100. When the SNR level is increased the estimation accuracy is decreased.

Conclusion: The simulation is performed in the MATLAB environment and the results obtained at different conditions. The performance comparison shows that ESPRIT algorithm performs better as compared to the AP-ML and AP-SSF.

\section{References:}

[1] R. Roy and T. Kailath, "ESPRITEstimation of signal parameters via rotational invariance techniques", IEEE Trans. Acoust. Speech, Signal Processing vol. ASSP-37, pp. 984-995, 1989.

[2] R. O. Schmidt, "Multiple emitter location and signal parameter estimation", IEEE Trans. Antennas Propagation vol. AP-34, pp. 276-280, 1986.

[3] J. A. Cadzow, "A high resolution direction of arrival algorithm for narrowband coherent and incoherent sources", IEEE Transaction of Acoustic Speech and Signal Processing, vol-36,pp-965-979,1988.

[4] Hamid Krim and Mats Viberg, -Two decades of array signal processing research: the parametric approach, IEEE Signal Processing Mag., vol. 13, pp. 67-94, 1996.

[5] J. Capon, "High Resolution frequency wave number spectrum analysis", IEEE Processing, vol 57, pp-1408-1418, 1969.

[6] I. Ziskind and M. Wax, "Maximum likelihood localization of multiple sources by alternating projection," in IEEE Transactions on Acoustics, Speech, and Signal Processing, vol. 36, no. 10, pp. 1553-1560, Oct. 1988.

\section{Creative Commons Attribution License 4.0 (Attribution 4.0 International, CC BY 4.0)}

This article is published under the terms of the Creative Commons Attribution License 4.0

https://creativecommons.org/licenses/by/4.0/deed.en US 